\title{
Multiple Cavernomas of the Brain: Simultaneous Hemorrhage of Two Lesions in a Non-Familial Form
}

\author{
Beyinde Multipl Kavernomlar: Ailesel Olmayan Formda İki Lezyonda Es \\ Zamanli Kanama
}

Pier Paolo PANCIANI, Alessandro AGNOLETTI, Riccardo FORNARO, Marco FONTANELLA, Alessandro DUCATI

University of Turin, Department of Neuroscience, Division of Neurosurgery, Via Cherasco, 15; 1026, Torino, Italy

Correspondence address: Pier Paolo PANCIANI / E-mail: vincy.bip@alice.it

\begin{abstract}
BACKGROUND: Cavernomas of the brain are congenital lesions clinically divided into hereditary and a sporadic forms. Multiple lesions are usually observed in the familial form, whereas the sporadic variant generally shows a single cavernoma. In this case we describe the simultaneous bleeding of two lesions in a patient with a non-familial cavernomatosis.

CASE DESCRIPTION: A 46-year-old woman presented with slight hyposthenia involving the left arm and cervical stiffness. Examinations revealed two cavernomas with recent signs of bleeding. The lesions were surgically removed achieving a total excision. The patient was discharged after 10 days with slight left hyposthenia.

DISCUSSION: Simultaneous hemorrhage of multiple cavernomas is rare. To the best of our knowledge, this is the first case showing a sporadic form presenting with two hemorrhagic lesions. We suggest an aggressive approach in order to avoid the risk of rebleeding, which is particularly high in case of hemorrhagic cavernomatosis.
\end{abstract}

KEYWORDS: Hemangioma, Cavernous, Central nervous system, Hemorrhage, Familial cerebral cavernous malformation

öz

AMAÇ: Beyin kavernomları klinik olarak herediter ve sporadik forma bölünen konjenital lezyonlardır. Multipl lezyonlar genellikle ailesel formda görülürken, sporadik varyantta genelde tek kavernom görülür. Bu olguda ailesel olmayan kavernomatosisi olan bir hastada iki lezyonda eş zamanlı kanama tanımlıyoruz.

OLGU SUNUMU: 46 yaşında bir kadın sol kolda hafif hiposteni ve servikal sertlikle geldi. Muayeneler yakın zamanlı kanama bulgularıyla iki kavernom gösterdi. Lezyonlar cerrahi olarak çıkarılıp tam eksizyon elde edildi. Hasta 10 gün sonra hafif bir sol hiposteniyle taburcu edildi.

TARTIŞMA: Multipl kavernomların eş zamanlı kanaması nadirdir. Bildiğimiz kadarıyla bu hasta iki hemorajik lezyonla gelen ilk sporadik form olgusudur. Özellikle hemorajik kavernomatoz olgularında yüksek olan tekrar kanama riskinden kaçınmak için agresif bir yaklaşım öneriyoruz.

ANAHTAR SÖZCÜKLER: Hemanjiyom, Kavernöz, Merkez sinir sistemi, Kanama, Ailesel serebral kavernöz malformasyon

\section{INTRODUCTION}

Cavernomas, also known as cavernous angiomas, are congenital malformations characterized by abnormal sinusoid-like capillaries adjacent to one another with little or no interposed cerebral parenchyma or muscular tissue.

The prevalence in the general population is $0.5-0.7 \%$, without any significant difference between genders (2). These lesions can be found at any age; $25 \%$ of cases are observed under 18 years old $(2,27)$. MRI is used for the diagnosis, especially in T2 WI (6). The clinical presentation may vary from asymptomatic forms, estimated to be $2-32 \%$, intracranial hemorrhage or seizures $(1,24-26)$.

Cavernomas can be clinically divided into 2 forms: sporadic and hereditary. In the sporadic form, single or few lesions are common ( $80 \%$ of cases). In the familial variant, multiple lesions can be found and they are exposed to an higher risk of hemorrhage. The inheritance is autosomal dominant with incomplete penetrance $(2,13,21)$. Therefore, the presence of multiple lesions is strongly suggestive for a familial form $(75 \%$ of cavernomatosis are hereditary) (13).

Surgery has a key role in the management of cavernomas, especially in lesions presenting with drug-resistant seizures (4).

In this report, we present a case of a non-familial cavernomatosis presenting with simultaneous bleeding of two lesions.

\section{DESCRIPTION of the CASE}

A 46-year-old woman with an uneventful clinical history presented with an episode of severe frontal headache, nausea 
and vomiting related with physical effort. At the admittance, the patient showed mild weakness (3/5) of the left arm and cervical stiffness.

The CT scan showed a large right-sided posterior superior frontal gyrus hemorrhagic lesion surrounded by edema causing compression of the right ventricle horn. A smaller hemorrhagic lesion was observed in the left anterior cingulate gyrus. The CT scan also showed other lesions of the left internal capsule (Figure 1). Successively, we performed a cerebral angiography that showed only indirect signs of the right lesion and a mild grade of compression of the deep venous structures. The patient was led to the operative theatre without MRI because of the sudden clinical worsening.

We performed the surgical excision of the two hemorrhagic lesions. Histological examination confirmed the clinical and radiological suspect of cavernomas according to WHO 2007 criteria.

The post-operative MRI showed the results of surgery and confirmed the presence of two more cavernomas in the anterior and posterior limb of the left internal capsule (Figure 2).

After surgery, the patient showed a persisting hyposthenia of the left arm (3/5). She had a mild meningeal reaction treated with antibiotic therapy and resolved without consequences.

The patient started a rehabilitative program. She was discharged after 10 days with residual hyposthenia of the left $\operatorname{arm}(4 / 5)$.

\section{DISCUSSION}

Multiple cavernomas of the brain are not uncommon. In large series of consecutive magnetic resonance scans in the general population, the incidence of cavernomas was $0.4 \%$. Of these, $18.7 \%$ were multiple (5). Other authors estimate multiple cavernomas to be about $20 \%$ of all cases (17). Therefore, cavernomatosis must be considered as a potential diagnosis in case of multiple brain lesions on MRI. A hereditary basis must always be assumed since multiple lesions in the sporadic form are rare (17). It is remarkable that $75 \%$ of cases showing multiple lesions are hereditary (13).
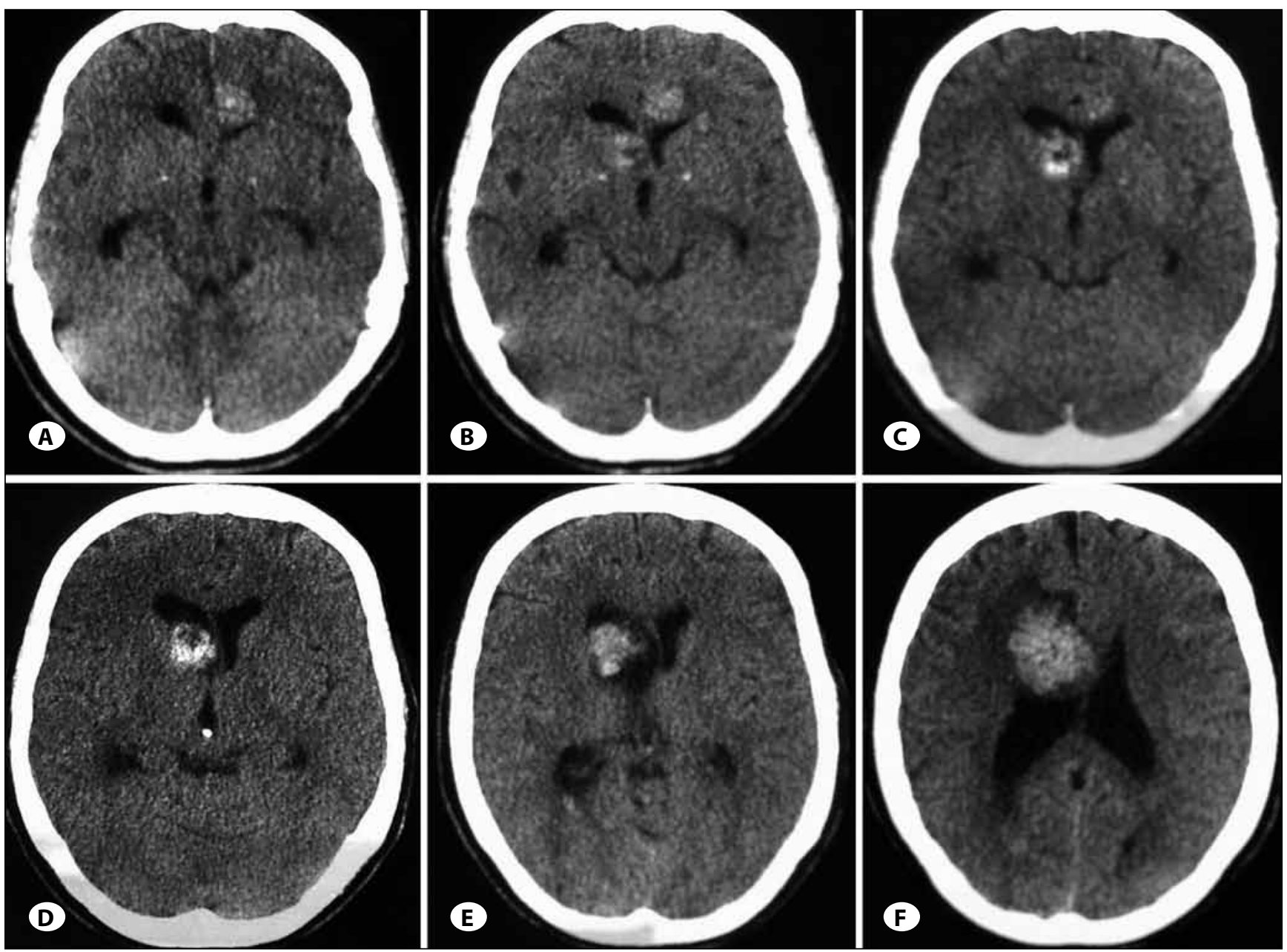

Figure 1: A) Hemorrhagic lesion in the left anterior cingulate gyrus, B) small left internal capsule lesion and thin bilateral basal ganglia hyperdensity, C,D) right-sided posterior superior frontal gyrus hemorrhagic lesion with edema E,F) compression of the right ventricle horn. 
On account of the high risk of a familial form, we decided to inform the relatives of our patient (parents, 1 brother, 1 sister, 2 children) on the possibility of being asymptomatic carriers of cerebral cavernomas. First, we talked to them in order to find out episodes suggestive for seizures. Anamnesis was unremarkable. Successively, we performed a series of MRI that excluded the presence of cavernomas in all cases. We concluded that our case was a sporadic form presenting with multiple hemorrhagic lesions.

The annual incidence of bleeding is estimated between 0.25 and $6.1 \%$ in sporadic form $(4,5,16,22)$, and it can reach $13 \%$ in the hereditary variant (28). The number of patients presenting with hemorrhage ranges from 20 to $57 \%(8,9,26)$. The risk of bleeding is influenced by many factors as deep anatomical location, female sex, pregnancy, brain radiotherapy, familial and multiple form of disease $(11,18,21,22)$. It is controversial whether hemorrhage increases the risk of rebleeding. Large series have shown contradictory results $(7,10,15,16,19,23)$. The mechanisms that may lead the patient to bleed are still uncertain.
Multiple cavernomas presenting with simultaneous hemorrhage of two or more lesions are extremely rare (3). This is the first case of a non-familial form of cavernomatosis with a simultaneous hemorrhage.

Computed tomography can show the presence of hemorrhagic lesions, but MRI is required for diagnosis (6). In our case, the postoperative MRI confirmed the diagnosis of cavernomatosis and showed the results of surgery of the bleeding lesions (Figure 2).

Surgical excision is recommended for favorably located cavernomas and for lesions showing intense mass effect (4). Multiple lesions, both in sporadic and in hereditary forms, increase the risk of bleeding. Therefore, we suggest an aggressive approach even in patients presenting with multiple cavernomas.

Surgery can rule out the risk of rebleeding, but the onset of "de novo cavernomas" must always be considered. It is suggestive for the familial form, even if a case without familial history has been reported (12). Factors influencing the onset
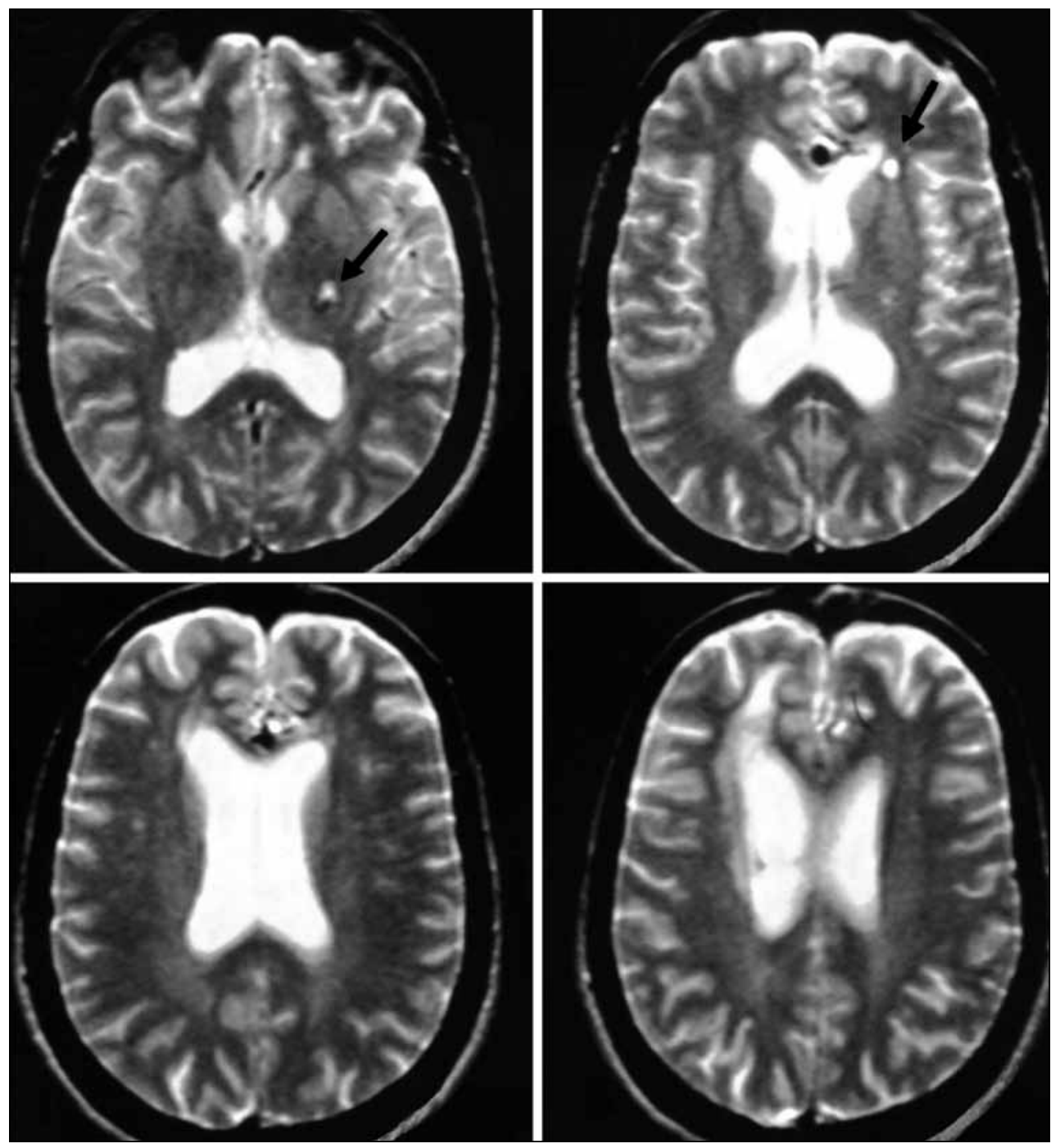

Figure 2: Post-operative MRI: cavernomas of the posterior and anterior limb of the left internal capsule; results of the left cingulate and right frontal gyrus cavernomas excision. 
of cavernomas are still unknown. Genetic alterations may be involved in the familial form (14). On the other hand, in the sporadic variant, cavernomas could result from the evolution of small unpredictable lesions following hemorrhages or capillary proliferation (20). Therefore, a MRI follow-up is suggested, especially in sporadic cases presenting with multiple hemorrhagic lesions.

\section{CONCLUSIONS}

Cavernomas should always be considered in case of multiple brain lesions on MRI. They are generally associated with the familial form, but even the sporadic variant can show multiple cavernomas. A surgical approach is recommended in any cases. The possible onset of "de novo cavernomas", especially in case of sporadic form presenting with multiple hemorrhagic lesions, may be evaluated by MRI follow-up.

\section{REFERENCES}

1. Aiba T, Tanaka R, Koike T, Kameyama S, Takeda N, Komata T: Natural history of intracranial cavernous malformations. J Neurosurg 83:56-59, 1995

2. Brunon J, Nuti C: Natural history of cavernomas of the central nervous system. Neurochirurgie 53:122-130, 2007

3. Chanda A, Nanda A: Multiple cavernomas of brain presenting with simultaneous hemorrhage in two lesions: A case report. Surg Neurol 57:340-344, 2002

4. Chazal J, Khalil T, Sakka L: Therapeutic indications for central nervous system cavernomas. Neurochirurgie 53:251-255, 2007

5. Del Curling O Jr, Kelly DL Jr, Elster AD, Craven TE: An analysis of the natural history of cavernous angiomas. J Neurosurg 75:702-708, 1991

6. Duong H, Del Carpio-O'Donovan R, Pike B, Ethier R: Multiple intracerebral cavernous angiomas. Can Assoc Radiol J 42: 329-334, 1991

7. Fritschi JA, Reulen HJ, Spetzler RF, Zabramski JM: Cavernous malformations of the brain stem. A review of 139 cases. Acta Neurochir (Wien) 130:35-46, 1994

8. Kim DS, Park YG, Choi JU, Chung SS, Lee KC: An analysis of the natural history of cavernous malformations. Surg Neurol 48:9-18, 1997

9. Kivelev J, Niemelä M, Kivisaari R, Dashti R, Laakso A, Hernesniemi J: Long-term outcome of patients with multiple cerebral cavernous malformations. Neurosurgery 65:450-455, 2009

10. Kondziolka D, Lunsford LD, Kestle JR: The natural history of cerebral cavernous malformations. J Neurosurg 83:820-824, 1995

11. Kupersmith MJ, Kalish H, Epstein F, Yu G, Berenstein A, Woo $H$, Jafar J, Mandel G, De Lara F: Natural history of brainstem cavernous malformations. Neurosurgery 48:47-54, 2001

12. Labauge $P$, Brunereau L, Coubes $P, C$ lanet $M$, Tannier C, Laberge S, Lévy C: Appearance of new lesions in two nonfamilial cerebral cavernoma patients. Eur Neurol 45:83-88, 2001

13. Labauge $P$, Laberge $S$, Brunereau L, Levy $C$, Tournier-Lasserve E: Hereditary cerebral cavernous angiomas: Clinical and genetic features in 57 French families. Société Française de Neurochirurgie. Lancet 352:1892-1897, 1998

14. Maiuri F, Cappabianca P, Gangemi M, De Caro Mdel B, Esposito F, Pettinato G, de Divitiis O, Mignogna C, Strazzullo $\mathrm{V}$, de Divitiis E: Clinical progression and familial occurrence of cerebral cavernous angiomas: The role of angiogenic and growth factors. Neurosurg Focus 21(1):E3, 2006

15. Mathiesen T, Edner G, Kihlström L: Deep and brainstem cavernomas: A consecutive 8-year series. J Neurosurg 99: 31-37, 2003

16. Moriarity JL, Wetzel M, Clatterbuck RE, Javedan S, Sheppard JM, Hoenig-Rigamonti K, Crone NE, Breiter SN, Lee RR, Rigamonti $D$ : The natural history of cavernous malformations: A prospective study of 68 patients. Neurosurgery 44: 1166-1173, 1999

17. Mosnier JF, Brunon J, Nuti C: Histopathology of central nervous system cavernomas. Neurochirurgie 53:131-135, 2007

18. Porter PJ, Willinsky RA, Harper W, Wallace MC: Cerebral cavernous malformations: Natural history and prognosis after clinical deterioration with or without hemorrhage. J Neurosurg 87:190-197, 1997

19. Porter RW, Detwiler PW, Spetzler RF, Lawton MT, Baskin JJ, Derksen PT, Zabramski JM: Cavernous malformations of the brainstem: experience with 100 patients. J Neurosurg 90: 50-58, 1999

20. Pozzati E, Acciarri N, Tognetti F, Marliani F, Giangaspero F: Growth, subsequent bleeding, and de novo appearance of cerebral cavernous angiomas. Neurosurgery 38:662-670, 1996

21. Rigamonti D, Hadley MN, Drayer BP, Johnson PC, HoenigRigamonti K, Knight JT, Spetzler RF: Cerebral cavernous malformations. Incidence and familial occurrence. N Engl J Med 319:343-347, 1988

22. Robinson JR, Awad IA, Little JR: Natural history of the cavernous angioma. J Neurosurg 75:709-714, 1991

23. Tarnaris A, Fernandes RP, Kitchen ND: Does conservative management for brain stem cavernomas have better longterm outcome? Br J Neurosurg 22:748-757, 2008

24. Vaquero J, Leunda G, Martínez R, Bravo G: Cavernomas of the brain. Neurosurgery 12:208-210, 1983

25. Voigt K, Yasargil MG: Cerebral cavernous haemangiomas or cavernomas. Incidence, pathology, localization, diagnosis, clinical features and treatment. Review of the literature and report of an unusual case. Neurochirurgia (Stuttg) 19:59-68, 1976

26. Washington CW, McCoy KE, Zipfel GJ: Update on the natural history of cavernous malformations and factors predicting aggressive clinical presentation. Neurosurg Focus 29(3):E7, 2010

27. Xia C, Zhang R, Mao Y, Zhou L: Pediatric cavernous malformation in the central nervous system: Report of 66 cases. Pediatr Neurosurg 45:105-113, 2009

28. Zabramski JM, Wascher TM, Spetzler RF, Johnson B, Golfinos J, Drayer BP, Brown B, Rigamonti D, Brown G: The natural history of familial cavernous malformations: Results of an ongoing study. J Neurosurg 80:422-432, 1994 